Buana Sains Vol 20 No 1: 87 - 98, 2020

\title{
POTENSI LANSKAP DESA PURWODADI SEBAGAI OBJEK DESA WISATA DI KABUPATEN MALANG
}

\author{
Debora Budiyono, Nuraini dan Alfiyah \\ Fakultas Pertanian, Universitas Tribhuwana Tunggadewi, Indonesia
}

\begin{abstract}
Purwodadi village is one of the village landscapes that has interesting natural and cultural potential to be developed as objects and attractions of toursim village. However the problem in Purwodadi village is not yet identified the potential of the landscape that can be developed into a tourism village object. Village tourism is one of the components between provided, accommodation and supporting facilities provided in the structure of the community with the prevailing order in the village. The purpose of this study was to identify the potential of the Purwodadi village landscape as a tourism village. The method used in the study is focus group discussion (FGD). Based on the identification results show that the village landscape of Purwodadi has 22 types of objects and potential attractions consisting of natural and cultural tourism. Natural potentials that can be developed are beaches, islands, agriculture, and animal husbandry. While the cultural potential consists of the offerings, art, carnival, and historical objects.
\end{abstract}

Keywords: : Purwodadi village; Regency of Malang; tourism object; tourism village; village landscape potential.

\section{Pendahuluan}

Kawasan perdesaan merupakan kawasan yang mempunyai kegiatan utama pertanian, termasuk pengelolaan sumberdaya alam dengan susunan fungsi kawasan sebagai tempat pemukiman perdesaan, pelayanan jasa pemerintahan, pelayanan sosial, dan kegiatan ekonomi (Adisasmita, 2010).

Lanskap pedesaan dapat disebut sebagai seluruh wilayah yang ada di tepi kota, suatu ruang yang memiliki pengaruh kecil terhadap kehidupan masyarakat. Lanskap pedesaan menunjukan unsur-unsur alam dan manusia pada kekuatan ekologis, ekonomi, dan budaya. Unsur lanskap tersebut membentuk pola yang kompleks dan berubah-ubah meliputi pertanian, masyarakat pedesaan, pengembangan pemukiman dan industri, habitat liar, tanah, air, dan tumbuhan (Coen et al., 1987).

Lanskap perdesaan merupakan perpaduan antara lanskap alami dan lanskap buatan yang berada pada sebuah desa. Lanskap tersebut memiliki sumber daya alam berupa sumber pangan dan habitat satwa liar, serta memiliki sumber daya manusia yang mampu hidup dan mempreservasi lingkungan ekologi yang alami. Berdasarkan kondisi tersebut lanskap pedesaan memiliki potensi pengembangan sebagai desa wisata.

Desa Wisata merupakan salah satu program pemerintah, yaitu Kementerian Pariwisata dan Ekonomi Kreatif, yang masuk dalam Program Nasional Pemberdayaan Masyarakat (PNPM) 
Mandiri yang diluncurkan pemerintah pada tahun 2009. Saat ini salah satu lanskap pedesaan yang memiliki potensi alam dan budaya yang belum dikembangkan sebagai objek daya tarik wiasata desa adalah Desa Purwodadi.

Kondisi ini dikarenakan latar belakang masyarakat desa yang kurang memahami arti penting lanskap yang dimiliki dan berpotensi sebagai objek dan atraksi wisata. Selain itu keterbatasan pemerintah dalam membantu pengembangan desa wisata. Oleh karena itu diperlukan identifikasi potensi lanskap Desa Purwodadi sebagai objek dan atraksi desa wisata. Dengan harapan Desa Purwodadi dapat mengembangkan alternatif-alternatif objek dan atraksi wisata yang dapat meningkatkan pendapatan masyarakat lokal serta menjaga kelestarian alam dan budaya.

\section{Metode Penelitian}

Kegiatan penelitian ini dilakukan pada bulan Maret sampai Juni 2019. Sedangkan batas lokasi penelitian berada Desa Purwodadi, Kabupaten Malang, Jawa Timur

Metode analisis penelitian ini menggunakan metode Focus Group Disccusion (Bungin, 2001). Metode ini digunakan sebagai sarana dalam menggali informasi tentang potensi lanskap Desa Purwodadi yang dapat dikembangkan sebagai objek dan atraksi wisata desa.

\section{Hasil dan Pembahasan}

\section{Sejarah Kawasan}

Tutupan lahan Desa Purwodadi pada umumnya adalah hutan dan lokasi hutan berada di kawasan Lenggoksono dan Widiawu. Namun pada tahun 1945 Desa Purwodadi dijadikan sebagai tempat pengungsian oleh masyarakat yang berasal dari Kabupaten Lumajang, kemudian tokoh pengungsi mengusulkan kepada kepala Desa Pujiharjo untuk membuka lahan yang ada di hutan Lenggoksono dan hutan Widiawu untuk mejadi Desa Purwodadi.

Pada tahun 1948 diadakan permohonan ulang yang didukung oleh saudara Armanu dan Mayor Abdul Kahar selaku pejabat komandan Sub. Teretorial komando VIII. Kemudian pada tanggal 2 April 1949 diresmikan lahan tersebut menjadi Dusun Lenggoksono dan Dusun Widiawu.

Pada tanggal 12 Januari tahun 1982 Desa Purwodadi melakukan pemekaran dari Desa Sumbertangkil yaitu berdasarkan keputusan Mendagri No. 146.1/20.8/PUOD tertanggal 5 Agustus 1981 (Lidah et al., 2009). Desa ini menjadi salah satu desa dari 13 desa yang berada dibawah naungan Kecamatan Tirtoyudo dengan luas wilayah \pm 1041 ha (Pemutahiran data Desa Purwodadi, 2008) yang terdiri dari tiga dusun diantaranya Dusun Balearjo, Dusun Lenggoksono, dan Dusun Purwodadi yang tersebar dalam 28 RT dan 6 RW.

\section{Kondisi fisik}

Desa Purwodadi memiliki topografi yang curam menurut Perhutani Malang. Topografi sangat berpengaruh dalam menentukan susunan rencana tapak dan harus peka dalam segala hal yang berhubungan dengan kondisi lahan yang ada (Laurie dalam Ganesya, 2014).

Desa Purwodadi memiliki musim hujan dan musim kemarau. Secara umum musim hujan terjadi pada bulan November-April, sedangan untuk musim kemarau terjadi pada bulan Mei- 
Oktober. Curah hujan yang terjadi pada Desa Purwodadi yaitu $2.100-2200 \mathrm{~mm}$ dengan suhu rata-rata harian $28-30{ }^{\circ} \mathrm{C}$ (Pemutahiran data Desa Purwodadi, 2019).

Jenis tanah yang terdapat pada Desa Purwodadi yaitu litosol dengan tekstur tanah lempung, struktur tanah liat dan sedikit berbatu, serta tanah memiliki tingkat kesuburan yang tinggi. Menurut Suroyo et al. (2013), jenis tanah litosol yaitu jenis tanah yang sangat mudah longsor yang terjadi apabila pada musim hujan yang berkepanjangan akan tetapi tanah ini memiliki tingkat kesuburan yang sangat cocok untuk bercocok tanam dalam segala hal tanaman yang akan ditanam.

Badan air yang digunakan oleh penduduk Desa Purwodadi bersumber dari mata air pegunungan yang mengelilingi desa dan PDAM. Penduduk Desa Purwodadi sangat memanfaatkan sumber air yang terdapat pada sungai utama yang bernama kali Purwo yang bercabang di bagian hulu. Aliran air sungai yang mengalir dimanfaatkan oleh masyarakat sekitar untuk mandi, cuci, dan kencing (MCK). Sedangkan untuk PDAM hanya digunakan oleh masyarakat kalangan atas, akan tetapi dalam penggunaan air PDAM ini dikenakan tarif perbulan dengan nominal pembayaran Rp. 10.000 /bulan.

Akses menuju Desa Purwodadi bisa dicapai melalui Kota Malang dan Kota Batu. Tranportasi menuju lokasi penelitian sangat mudah untuk dijangkau dari Kota Malang, akan tetapi pada saat sampai di Dampit transportasi yang digunakan yaitu angkutan umum yang jumlahnya sangat terbatas dengan jadwal hanya satu trip yaitu 04.30 - 05.00 WIB (dari desa menuju Dampit) dan pukul 10.30 - 12.00 WIB (kembali dari Dampit menuju Desa Purwodadi).
Jarak yang perlu ditempuh menuju lokasi penelitian yaitu $69,8 \mathrm{~km}$ dengan jangka waktu yang dibutuhkan yaitu 3 jam jika ditempuh menggunakan tranportasi ojek sedangkan jika menggunakan tranportasi bus dapat dijangkau dengan jangka waktu 1,5 jam dengan jarak tempuh $43 \mathrm{~km}$ dari terminal Arjosari menuju Dampit. Jenis mobil angkutan yang digunakan dari Dampit menuju Desa Purwodadi yaitu mobil jenis bison yang didalamnya hanya dapat mengangkut penumpang berjumlah 15 orang.

\section{Kondisi Biofisik}

Desa Purwodadi memiliki ekosistem hutan lindung, hutan produksi, sungai, dan laut. Keberadaan flora dan fauna yang terdapat pada Desa Purwodadi merupakan potensi yang saling berkaitan. Oleh karena itu, dibutuhkan upaya untuk menjaga dan melestarikan sumberdaya tersebut dan tidak merusaknya. Jenis fauna yang sering ditemui oleh masyarakat Desa Purwodadi yaitu berupa jenis aves, unggas, mamalia, reptilian, dan fillum Mollusca.

Jenis aves dan unggas yang ditemui dan serig terdengar bunyinya yaitu ayam (Gallus domesticus), burung merpati (Columba livia domestica), burung kutilang (Pynonotus aurigaster), burung bangau (Mycteria cinerea), burung walet (Collocalia vestita), burung gereja (Passeridae), burung kendet (Lanius schach), burung peranjak (Prinia familiaris), burung laut (Phalaropidae), burung jalak (Sturnus nigricollis), Burung murai (Copsychus malabaricus), Burung kedasih (Surniculus lugubris), burung hantu (Strix aluco), ayam hutan (Gallus varius), burung lovebird (Argopornis personata), burung cerukcuk (Pycnonotus goiaviar), dan burung kamade (Dicaeum trochileum). 
Jenis fauna yang berupa mamalia, reptilia, dan fillum molusca yaitu terdiri dari kelelawar (Chiroptera), biawak (Varanus), ular sawah (Python reticulatus), ular daun (Ahaetulla), ular cobra (Naja), monyet ekor panjang (Macaca fascicularis), monyet hitam (Macaca nigra), bajing (Sciuridae), luwak (Paradoxurus hermaphroditus), tupai kekes (Tupaia javanica), tupai (Scandentia), musang (Paradoxurus hermaphroditus), cacing (Lumbricina), semut (Formicidae), keong pohon (Amphidromus), babi (Sus), anjing (Canis lupus familiaris), kambing ternak (Capra aegagrus hircus), kucing (Felis catus), dan kadal (Lacertilia).

Jenis pisces yang terdapat pada Desa Purwodadi terdiri dari sejenis ikan yang berupa tongkol (Euthynnus affinis), layur (Trichiurus lepturus), cucut (Rhizoprionodon acutus), kembung (Rastrelliger faughni), layang (Decafterus ruselli), selar (Selaroides leptolepis), japuh (Dussumeiria spp), tembang (Sardinella fimbriata), lemuru (Sardinella longiceps), teri (Engraulidae), ekor kuning (Caesionidae), kuwe (Caranx ignobilis), sunglir (Elagastis bipinnu latus), layur (Trichiurus lepturus), pari (Dasyatidae), hiu (Selachimorpha), lumba-lumba (Delphinus capensis), dan paus (Balaenoptera musculus).

Jenis fillum molusca dan artopoda ang terdapat pada desa ini yaitu terumbu karang, keong laut (Gibbula divaricata), cumi-cumi (Decapodi formis), lobster (Nephropidae), kerang (Anandara granosa), penyu (Chelonioidae), udang (Caridea), rajungan (Portunus pelagicus), Sotong (Sepiida), gurita (Octopoda), teripang (Holothuroidea), bintang laut (Crinoidea) dan. Sedangkan padang lamun yang terdapat pada desa ini terdiri dari berbagai jenis lamun diantaranya adalah Halodule sp, Cymodocea sp, Syiringodium sp, Holopila sp, Enhalus acoroides, Thalassia hemprichii, Thalassodendron ciliatum, dan Thalassia cilliatum (Lidah et al., 2009).

\section{Kondisi Sosial dan Budaya}

Jumlah penduduk masyarakat Desa Purwodadi yaitu 5.363 jiwa, dengan jumlah laki-laki sebanyak 2.744 jiwa sedangkan perempuan berjumlah 2.619 jiwa. Penduduk Desa Purwodadi sebagian besar bermata pencaharian sebagai petani, pedagang, nelayan, karyawan perusahan swasta, dan peternak.

Penduduk Desa Purwodadi mempuyai tiga keyakinan agama yang dianut. Sebagian besar Desa Purwodadi memeluk agama islam dengan jumlah 3.482 jiwa, agama kristen 1.880 jiwa, dan agama hindu berjumlah 1 jiwa. Keragaman masayarakat Desa Purwodadi dapat saling membaur dan saling menghormati satu sama lain. Hal ini sangat penting dalam pengembangan sebuaah desa wisata.

Menurut Gun (1994), sebuah wisata yang baik, berhasil, dan berkelanjutan apabila kegiatan wisata melibatkan semua komponen masyarakat. Dimana masyarakat lokal termasuk penggerak dan pelaku wisata. Hal ini juga dikemukakan juga oleh Budiyono (2013), bahwa keberhasilan wisata yang berkelanjutan apabila semua stakeholder dapat bekerjasama seperti pemerintah pusat dan daerah, masyarakat lokal, swasta (investor), dan lembaga swadaya masyarakat (LSM).

\section{Daya Tarik Wiasta}

Desa Purwodadi mempunyai daya tarik wisata berupa panorama alam dan sosial budaya. Berdasarkan data dari POKDARWIS (2019), jumlah 
pengunjung Desa Purwodadi mengalami peningkatan setiap tahunnya dengan tujuan mengunjungi objek dan atraksi (Tabel 1).

Tujuan utama wisatawan asing berkunjung ke Desa Purwodadi yaitu melihat view pemandangan pantai, surfing, dan belajar budaya masyarakat lokal dengan rata-rata paling lama 1-7 hari. Sedangkan untuk wiatawan lokal berkunjung dengan tujuan melihat view pemandangan pantai, diving, tracking, snorkeling, dan surfing. Selain itu fasilitas yang dimiliki desa cukup memadai atas bantuan pemerintah. POKDARWIS Desa Purwodadi menjual paket wisata kepada wisatawan ataupun pihak travel (Tabel 2). Fasilitas yang terdapat pada Desa Purwodadi dapat dilihat pada Tabel 2.

Penilaian potensi daya tarik objek dan atraksi wisata di Desa Purwodadi dilakukan dengan teknik Focus Group Disccusion (FGD). FGD dilakukan dengan stakeholder yaitu masyarakat desa yang terdiri dari 8 peserta yaitu
POKDARWIS dan Karang Taruna. Berdasarkan hasil diskusi dengan stakeholder ditetapkan 22 jenis objek yang dapat berpotensi sebagai objek desa wisata. Objek dan atraksi dinilai berpotensi dikembangkan atas dasar keunikan, kelangkaan, keaslian, keindahan, kesejarahan, dan aksesbilitas.

\section{Potensi Objek dan Atraksi Desa Wisata}

Potensi objek dan atraksi desa wisata di Desa Purwodadi yaitu potensi alam dan budaya yang dapat dikembangkan adalah pantai, pulau, pertanian, dan peternakan. Sedangkan potensi budaya terdiri dari aktivitas pertanian, larung sesaji, kesenian, karnaval, dan benda-benda bersejarah. Menurut Inskeep (1985), objek wisata adalah suatu keadaan alam dan perwujudan ciptaan manusia, tata hidup, seni budaya, sejarah, dan tempat yg memiliki daya tarik untuk dikunjungi wisatawan.

Tabel 1. Jumlah Pengunjung

\begin{tabular}{cccc}
\hline No & Tahun & & Jumlah \\
\cline { 3 - 4 } & & Wisman & Wisnus \\
\hline 1 & 2015 & 101 Jiwa & 37.287 Jiwa \\
2 & 2016 & 1.147 Jiwa & 32.699 Jiwa \\
3 & 2017 & 403 Jiwa & 44.539 Jiwa \\
4 & 2018 & 268 Jiwa & 33.481 Jiwa \\
5 & 2019 & 93 Jiwa & 13.691 Jiwa \\
\multicolumn{3}{c}{} \\
\hline \multicolumn{3}{c}{ (Sanuari- } \\
April)
\end{tabular}


Tabel 2. Fasilitas Desa Purwodadi

\begin{tabular}{|c|c|c|c|c|}
\hline No & Jenis & Jumlah & Kondisi & Fungsi \\
\hline 1 & Loket masuk & 1 & Baik & Penerima \\
\hline 2 & Home stay & 9 & Baik & Penginapan \\
\hline 3 & Jatskey & 3 & Baik & Olahraga air \\
\hline 4 & Papan selancar & 20 & Baik & Olahraga air \\
\hline 5 & Pelampung & 35 & Baik & Snorckling \\
\hline 6 & Alat Diving & 5 & Baik & Menyelam \\
\hline 7 & Perahu & 25 & Baik & Berperahu \\
\hline 8 & Gazebo & 6 & Baik & Istirahat \\
\hline 9 & Tempat jualan & 5 & $\begin{array}{l}\text { Kurang } \\
\text { baik }\end{array}$ & $\begin{array}{l}\text { Makan dan } \\
\text { minum }\end{array}$ \\
\hline 10 & $\begin{array}{l}\text { Tempat } \\
\text { sampah }\end{array}$ & 4 & $\begin{array}{l}\text { Kurang } \\
\text { baik }\end{array}$ & $\begin{array}{l}\text { Wadah } \\
\text { Sampah }\end{array}$ \\
\hline 11 & Motor gunung & 5 & Baik & $\begin{array}{l}\text { Mendaki } \\
\text { gunung }\end{array}$ \\
\hline 12 & Toilet & 2 & $\begin{array}{l}\text { Cukup } \\
\text { baik }\end{array}$ & Toilet \\
\hline 13 & Spot photo & 1 & $\begin{array}{l}\text { Kurang } \\
\text { baik }\end{array}$ & Spot photo \\
\hline 14 & $\begin{array}{l}\text { Tali panjat } \\
\text { tebing }\end{array}$ & 1 & Baik & $\begin{array}{l}\text { Panjat } \\
\text { tebing }\end{array}$ \\
\hline 15 & Rambu-rambu & 2 & $\begin{array}{l}\text { Kurang } \\
\text { baik }\end{array}$ & $\begin{array}{l}\text { Peraturan } \\
\text { pengunjung }\end{array}$ \\
\hline 16 & Ayunan & 1 & Baik & Berayun \\
\hline
\end{tabular}

Sedangkan atraksi adalah semua perwujudan, sajian alam, dan kebudayaan yg dapat dinikmati (dilihat, didengar, dan dirasakan) keberadaannya oleh wisatawan, yg alami dan man made, melalui suatu bentuk pertunjukkan atau peragaan atau kebiasaan (pasif dan aktif) yamg khusus diselenggarakan untuk wisatawan di suatu kawasan. Potensi objek dan atraksi wisata di Desa Purwodadi adalah:

1. Pantai Lenggoksono

$$
\text { Potensi Pantai Lenggoksono }
$$
memiliki potensi pasir putih yang panjang dan ombak pantai yang cukup tinggi sehingga sangat cocok untuk olahraga air. Pengunjung wisata dapat melakukan aktivitas surfing, kano, memancing, berenang, snorkeling, menikmati pemandangan yang indah, bermain pasir, bermain ayunan pantai, camping, berphoto, dan kuliner hasil laut (Gambar 1).

2. Banyu Anjlok

Potensi Banyu Anjlok merupakan salah satu pantai yang indah karena kombinasi antara pantai dan air terjun (Gambar 2). Pengunjung wisata dapat berenang, mandi, bermain pasir, menikmati pemandangan alam, dan berphoto. 


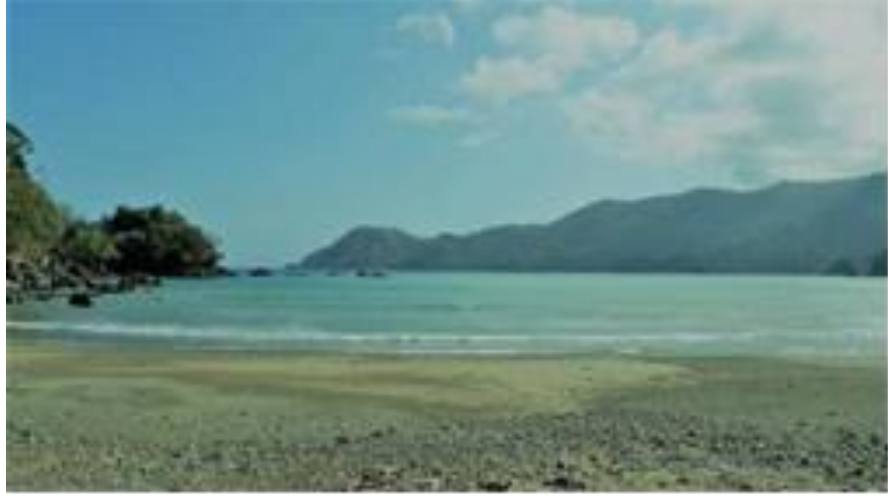

Gambar 1. Pantai Lenggoksono

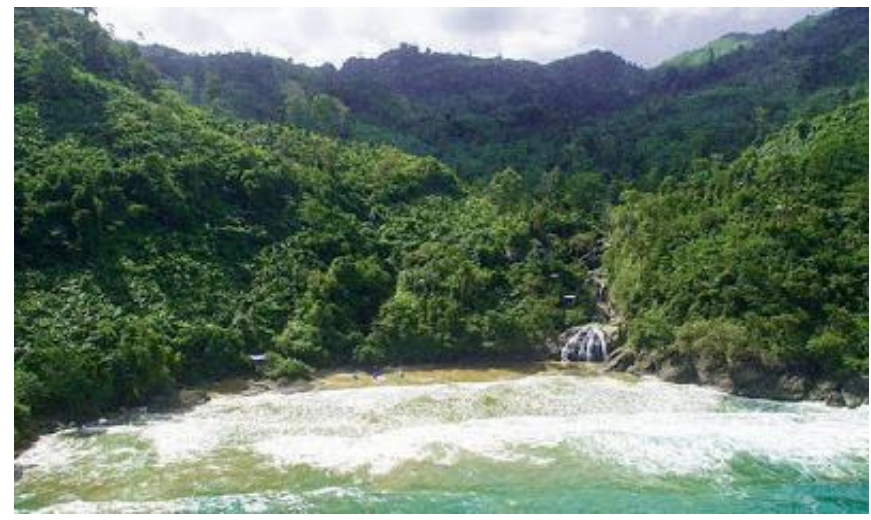

Gambar 2. Banyu Anjlok

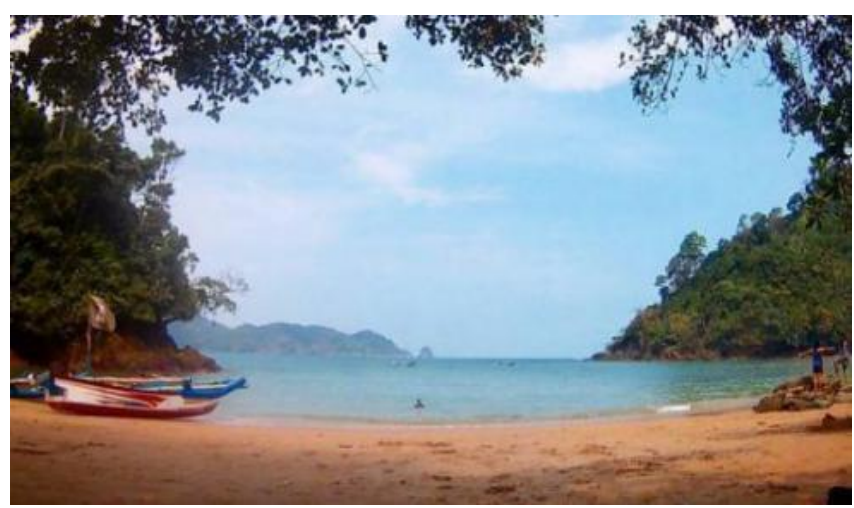

Gambar 3. Pantai bolu-bolu 


\section{Pantai Bolu-bolu}

Potensi Pantai Bolu-bolu memiliki potensi pasir putih dan ombak yang tenang (Gambar 3). Pengunjung wisata dapat melakukan aktivitas berenang, kano, camping, bermain pasir, memancing, berphoto, dan meikmati pemandangan indah.

\section{Pantai Wedi Putih}

Potensi Pantai Wedi Putih memiliki potensi pasir putih, ombak yang tenang, dan batu karang. Pengunjung wisata dapat melakukan aktivitas berenang, bermain pasir, berphoto, dan meikmati pemandangan indah.

\section{Pantai Dampar}

Potensi Pantai Dampar memiliki potensi pasir putih dan laut jernih yang cukup tenang. Pengunjung wisata dapat melakukan aktivitas berenang, bermain pasir, berphoto, dan meikmati pemandangan indah.

\section{Pantai Wedi Awu}

Potensi Pantai Wedi Awu merupakan salah satu pantai yang memiliki potensi pasir putih yang cukup panjang dan ombak tinggi. Pengunjung wisata dapat melakukan aktivitas surfing, kano, jet ski, berenang, bermain pasir, berphoto, kuliner, dan meikmati pemandangan indah.

\section{Pantai Kleta'an}

Potensi Pantai Kleta'an merupakan salah satu pantai yang memiliki potensi pasir putih dan ombak yang tenang. Pengunjung wisata dapat melakukan aktivitas berenang, snorkeling, diving, bermain pasir, berphoto, dan meikmati pemandangan indah.

\section{Pulau Pat}

Potensi Pulau Pat memiliki potensi ombak yang tenang dan pemandangan yang indah. Pengunjung wisata dapat melakukan aktivitas berenang, snorkeling, memancing, berphoto, dan meikmati pemandangan indah.

\section{Pulau Gadung}

Potensi Pulau Gadung memiliki potensi ombak yang cukup tenang dan pemandangan yang indah. Pengunjung wisata dapat melakukan aktivitas memancing, berphoto, dan meikmati pemandangan indah.

\section{Pulau Pakis}

Potensi Pulau Pakis memiliki potensi ombak yang cukup tenang dan pemandangan yang indah (Gambar 4). Pengunjung wisata dapat melakukan aktivitas berphoto, mencari kerang, dan meikmati pemandangan indah.

\section{Coban Tempuran}

\section{Potensi Coban Tempuran} merupakan kawasan air terjun yang memiliki air yang jernih dan cukup tenang di Desa Purwodadi (Gambar 5). Pengunjung wisata yang datang dapat melakukan aktivitas brenang, berphoto, pemandian, dan meikmati pemandangan indah.

\section{Persawahan}

Potensi persawahan pedesaan memiliki potensi agrowisata yang sangat menarik. Pengunjung wisata dapat menikmati atraksi para petani pada saat bercocok tanam dan waktu panen. Selain itu pemandangan sawah yang indah ketika musim padi hijau dan kekuningan.

\section{Omah Bowele}

Potensi Omah Bowele memiliki potensi agrowisata yang sangat menarik (Gambar 6). Pengunjung wisata dapat melakukan tracking dan metik buah pisang serta terdapat penginapan.

\section{Tambak Udang}

Potensi tambak udang merupakan milik masyarakat di Desa Purwodadi. Pengunjung wisata yang datang dapat melakukan aktivitas tambak udang dan kuliner pada saat panen raya.

\section{Budidaya Burung Walet}

Salah satu potensi wisata peternakan yang dimiliki adalah budidaya burung walet. Pengunjung wisata yang datang dapat melakukan aktivitas melihat cara beternak walet. 
Debora Budiyono, Nuraini dan Alfiyah/ Buana Sains Vol 20 No 1 : 87-98

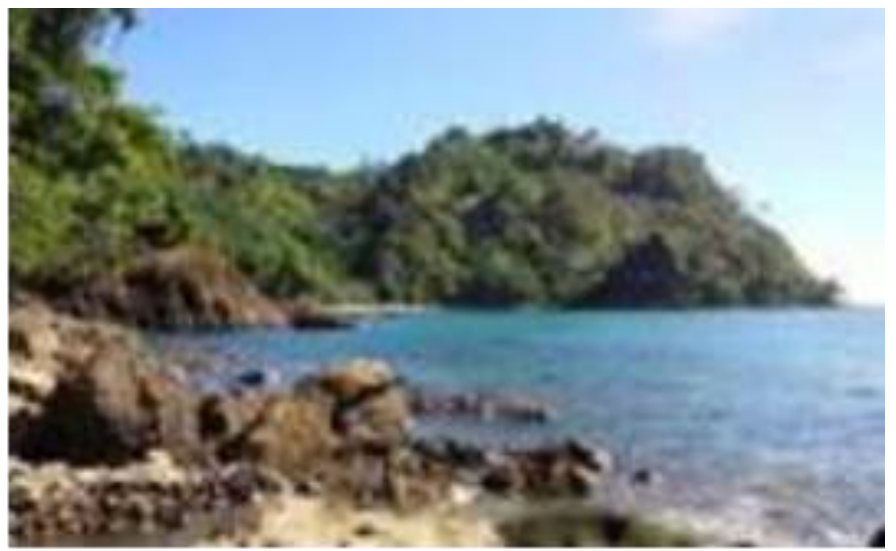

Gambar 4. Pulau pakis

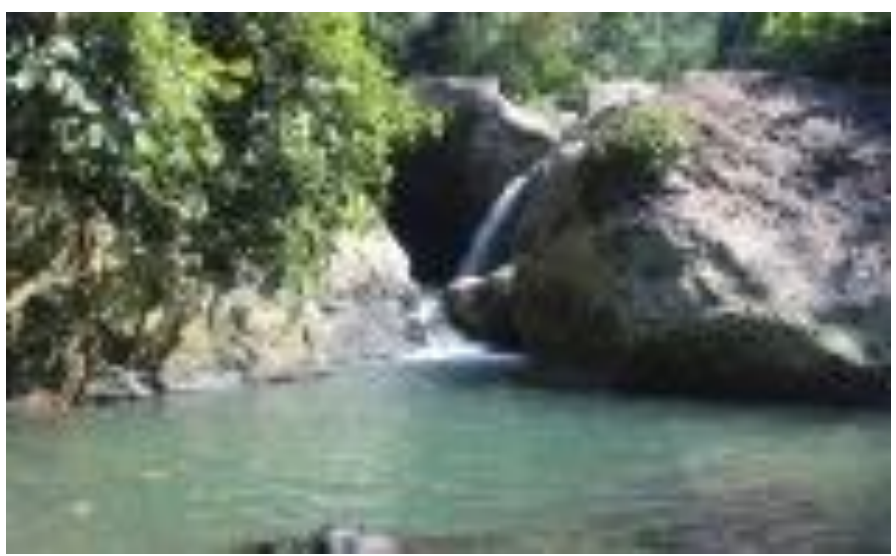

Gambar 5. Coban tempuran

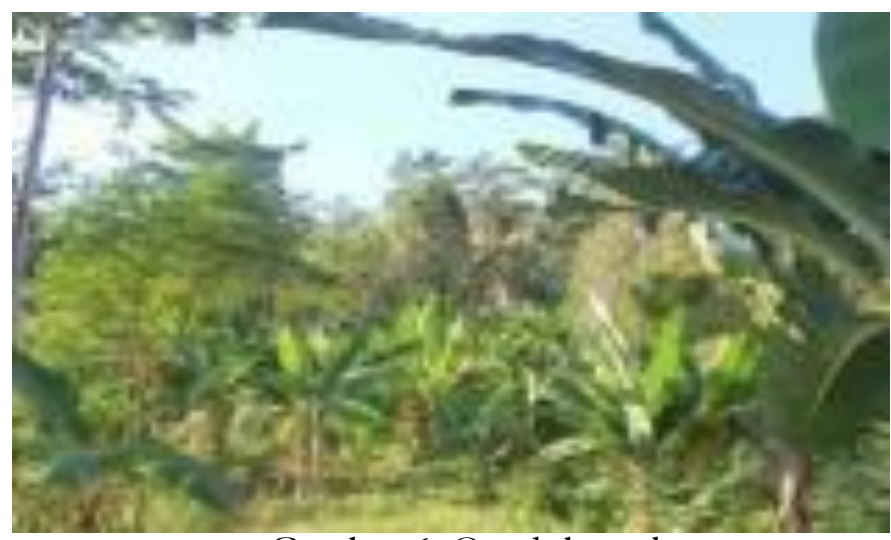

Gambar 6. Omah bowale 


\section{Petik dan Penyulingan Cengkeh}

Salah satu potensi agrowisata yang dimiliki adalah kebun cengkeh. Pengunjung wisata yang datang dapat melakukan aktivitas melihat petik cengkeh dan cara proses penyulingan cengkeh secara tradisional.

\section{Rumah Joglo}

Potensi arsitektur rumah Jawa tradisional adalah Joglo. Pengunjung wisata dapat belajar konsep arsitektur rumah Joglo dan aktivitas masyarakat Desa Purwodadi.

\section{Budaya Larung Sesaji}

Budaya Jawa seperti Larung Sesaji dilakukan setiap tahun di Desa Purwodadi sejak 1982. Pengunjung wisata dapat belajar budaya masyarakat.

\section{Pentas kesenian}

Budaya pentas seni yang dilakukan setiap tahun Pengunjung wisata dapat belajar tarian, musik tradisional, dan pencak silat.

\section{Karnaval}

Budaya karnaval yang dilakukan setiap tahun sebagai merayakan kemerdekaan Indonesia yang dilakukan setiap tahun pada tanggal 28 Agustus. Pengunjung wisata dapat melihat arak-arakan dan lomba desa.

\section{Peletakan Batu Pertama}

Monumen batu peletakan pertama dilakukan setiap tahun pada bulan Suro di Desa Purwodadi.

Pengunjung wisata dapat belajar sejarah pertama kali masyarakat desa tinggal.

\section{Pohon Bersejarah}

Pohon yang memiliki nilai sejarah adalah pohon durian. Pengunjung wisata dapat melihat pohon yang ditanam semenjak desa didirikan dan ikut panen durian pada saat berbuah.

\section{Kesimpulan}

Desa Purwodadi merupakan salah satu lanskap desa yang memiliki potensi alam dan budaya yang menarik untuk dikembangkan sebagai objek dan atraksi desa wisata. Berdasarkan hasil identifikasi menunjukan bahwa lanskap desa Purwodadi memiliki potensi objek dan atraksi sebanyak 22 jenis yang terdiri dari wisata alam dan budaya. Potensi alam yang dapat dikembangkan adalah pantai, pulau, pertanian, dan peternakan. Sedangkan potensi budaya terdiri dari aktivitas larung sesaji, kesenian, karnaval, dan benda bersejarah.

\section{Daftar Pustaka}

Adisasmita R. 2010. Pembangunan Kawasan dan Tata Ruang. Yogyakarta: Graha Ilmu.

Budiyono D, Nurisjah S, dan Adriyanto L. 2013. Perencanaan Lanskap Kawasan Wisata Pesisir Lalong Kota Luwuk, Sulawesi Tengah. Jurnal Lanskap Indonesia Vol 5 No 22013.

Bungin B. 2001. Metodelogi Pendidikan Kualitatif. Jakarta: Rajawali Press.

Coen D, Nassauer JI, Tuttle R. 1987. Landscape Architecture in the Rural Landscape. Wasington:ASLA.

Ganesya RA. 2014. Perencanaan Lanskap Wisata Alam di Wana

Wisata Penangkaran Rusa Kecamatan Tanjung Sari Bogor [skripsi]. Bogor: Institut Pertanian Bogor.

Gunn CA. 1994. Tourism Planning: Basic, Concept, Case. Third Edition. Taylor and Francis. Wangshington DC.

Inskeep E. 1991. Tourism Planning: An Integrated and Sustainble Development Approach van Nosttrand Reinhold. New York. USA. 
Lidah P, Kusumaningrum A, dan Dwijaya A.

2009. Laporan Zonasi dan Tata Ruang Desa

Purwodadi Kecamatan Tirtoyudo.

Pengelolaan lingkungan berbasis

pemberdayaan masyarakat (PLBM).

Suroyo, Suntoro, dan Suryono. 2013. Sistem

Tumpangsari dan Integrasi Ternak Terhadap Perubahan Sifat Fisik dan Kimia Tanah Litosol.

Jurnal Ilmu Tanah dan Agroklimatologi Vol 10 No 12013. 
